\title{
ULTRASOUND OBSERVATIONS OF OVARIAN STRUCTURES IN COWS DURING INTRAVAGINAL PROGESTERONE DEVICE APPLICATION AND IN THE FOLLOWING SEXUAL CYCLE (PRELIMINARY REPORT)
}

\author{
R. DOLEŽEL1, K. KARLBERG ${ }^{2}$, E. ROPSTAD ${ }^{2}$ and Kristina LANDSVERK ${ }^{3}$
}

${ }^{1}$ Clinic of Obstetrics, Gynaecology and Andrology, University of Veterinary and Pharmaceutical Sciences, 61242 Brno

${ }^{2}$ Department of Reproduction and Forensic Medicine, Norwegian College of Veterinary Medicine, Oslo, Norway

${ }^{3}$ Norwegian Red Cattle Association, Hamar, Norway

Received September 18, 1992

\begin{abstract}
Doležel, R., K. Karlberg, E. Ropstad, Kristina Landsverk: Ultrasound Observations of Ovarian Structures in Cows during Intravaginal Progesterone Device Application and in the Following Sexual Cycle (Preliminary Report). Acta vet. Brno, 62, 1993: 179-185.

Pluriparous dairy cows (Norwegian cattle) were used in experiment. Intravaginal progesterone devices (CIDR) were inserted in 4 experimental cows from day $14-$ 15 to day $24-25$ postpartum. Four cows in the same postpartal period were included in a control group. The cows were examined by transrectal ultrasonography at 3 and 4 day alternating intervals from day $9-10$ post partum until the 2 nd ovulation. Three times weekly the samples of whole milk were taken for progesterone investigation by RIA. Follicle population was divided into 3 groups: small $(4-6 \mathrm{~mm})$, medium $(7-10 \mathrm{~mm})$ and large $(>10 \mathrm{~mm})$. None of experimental cows had $\mathrm{CL}$ before and during CIDR period. Dominant large follicles slowly grew during CIDR period and ovulated day 3 and 4 after CIDR removal. The first dominant medium follicle occurred in one experimental cow days 1 after CIDR insertion, it persisted and became atretic. Second dominant large follicle was observed at the 1st day after CIDR removal and ovulated 8 days later. Medium follicles did not change and number of small follicles increased during CIDR period. One and two follicular waves were discovered in control cows which ovulated before and after day 20 postpartum. Term of the 1 st postpartal ovulation (day postpartum $30 \pm$ 3.37 vs $19.5 \pm 7.85)$, length of the 1 st sexual cycle $(24.0 \pm 2.45$ vs $18.0 \pm 5.35$ days), and number of follicular waves during the 1 st sexual cycle $(2.5 \pm 0.58$ vs $2.0 \pm 0.82$ ) in experimental and control cows were different. Values of milk progesterone during CIDR period $(0.7-1.4 \mathrm{ng} / \mathrm{ml})$ were significantly higher $(\mathrm{p}<0.01)$ in comparison with values before CIDR insertion and during the same postpartum period in non-ovulatory control cows. A 10-day-CIDR treatment is a possible method for induction of the 1st ovulation followed by a normal sexual cycle in postpartal cows.
\end{abstract}

Dominant follicle, follicular wave, postpartal ovulation, milk progesterone, CIDR device

Initiation of early postpartal luteal phase using progestagen treatment (or pretreatment) for several days is considered to be a useful method for induction and/or synchronization of the first postpartal ovulation followed by normal luteal phase in cows. Progestagen implants (Gauthier et al. 1985), vaginal devices (Smith et al. 1987) and parenteral or oral drugs (Fulton et al., 1978; Rutter et al., 1985) have been used for this purpose. Long term progestagen treatment is followed by a lower conception rate (Zimbelman 1963; Thimonier et al. 1975). Reduced fertility may 
contribute to altered follicular development (Lamond et al., 1971). On the other hand Sheffel et al. (1982) and Troxel and Kesler (1984) state that progesterone pretreatment increases the proportion of cows which formed corpus luteum of normal lifespan and according to White et al. (1985) and Smith (1986) quality and lifespan of CL is influenced by follicular development.

The objectives of our study were to ultrasonographically observe ovarian structures (follicles and corpora lutea) during progestagen treatment (intravaginal progesterone device for 10 days) and the following sexual cycle in postpartal cows.

\section{Materials and Methods}

Pluriparous dairy cows (Norwegian cattle) calving between August 13 and October 1 were used in the experiment. Animals were housed and were fed a grass silage, hay, and concentrates. The calves were removed just after parturition. The cows were milked twice daily and they were detected for estrus twice daily by visual observation. Intravaginal progesterone devices (EAZIbreed CIDR B, Carter Holt Harvey Plastic Products, New Zealand) were inserted in 4 cows from day $14-15$ to day $24-25$ after calving. Four cows without intravaginal devices were included in the control group. The cows were examined by transrectal ultrasonography using a linear array ultrasound scanner equipped with a $5 \mathrm{MHz}$ rectal probe (Scanner 403, PIE Medical, The Netherlands) at 3 and 4 alternating intervals from day 9-10 after calving until the 2nd ovulation One experimental cow was regularly investigated from the 1st postpartal ovulation. Different planes of each ovary were examined, ultrasound images were frozen and printed using a video copy processor (Model P61E, Mitsubishi, Japan). Ovarian structures (follicles $>3 \mathrm{~mm}$, corpora lutea) were individualy identified by reference to their position and diameter in sequential images. Gradual growth of a dominant follicle (at least $2 \mathrm{~mm}$ in diameter more than other follicles) was considered as a follicular wave. End of a follicular wave was determined as the time from which the diameter of a dominant follicle was not increased and the second large follicle began to grow or as the time of disappearance of this follicle not followed by the formation of a CL. Day after estrus was determined as the term of ovulation. If estrus was not observed the time between occurrence and disappearance of the largest follicle followed the by formation of a CL was determined as the term of ovulation. The largest follicle at day 9-10 after calving was considered as the first postpartal dominant follicle. Three times weekly the samples of whole milk were taken from day 9-10 to day $30-31$ after calving and stored at $-20^{\circ} \mathrm{C}$ until they were assayed for progesterone by RIA. Student's t-test was used for statistical evaluation.

\section{Results}

Occurrence of small $(4-6 \mathrm{~mm})$, medium $(7-10 \mathrm{~mm})$, and large $(>10 \mathrm{~mm})$ follicles in experimental cows from day $9-10$ to day $30-31$ post partum (pp) is shown in Fig. 1. First postpartal dominant follicle was discovered in two experimental cows before inserting CIDR devices. These large follicles slowly grew during the CIDR period and they ovulated at day 3 and 4 after the removal of intravaginal devices. Non dominant follicle was discovered in one experimental cow before insertion of CIDR device. The first dominant follicle occurred in this cow on day 1 after insertion of the CIDR device. Likewise, this dominant medium follicle persisted during CIDR period but it did not ovulate and became atretic. Second dominant large follicle was observed on the 1st day after removal of CIDR device and it ovulated 8 days later. The diameters and numbers of medium follicles did not change during the CIDR period. Diameters of large follicles slightly increased. Number of small follicles increased in experimental cows by the end of the CIDR period. Characteristic appearance of CL was discovered in ultrasound image after the 1st ovulation.

Frequent changes were observed in the diameters and numbers of follicles in control cows from day 9-10 to day 30-31 pp. Medium and/or large non-ovulatory follicles developed each week. One preovulatory follicular wave was 
discovered in control cows which ovulated before day $20 \mathrm{pp}$. Two follicular waves were discovered in control cows which ovulated later.

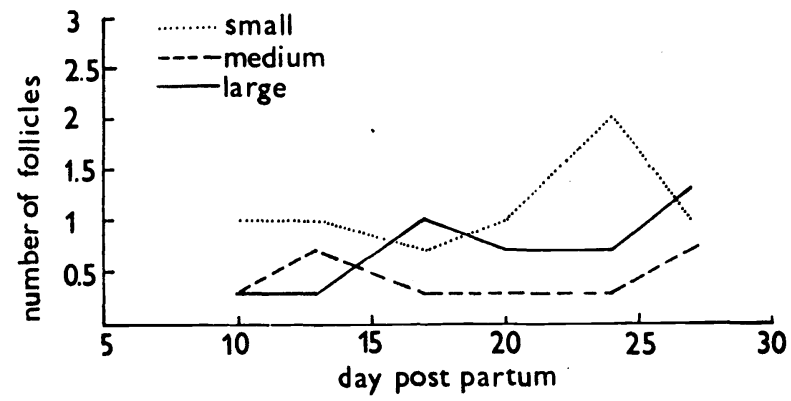

Fig. 1. Average number of small $(4-6 \mathrm{~mm})$, medium $(7-10 \mathrm{~mm})$ and large $(11 \mathrm{~mm}$ and more) follicles in experimental cows.

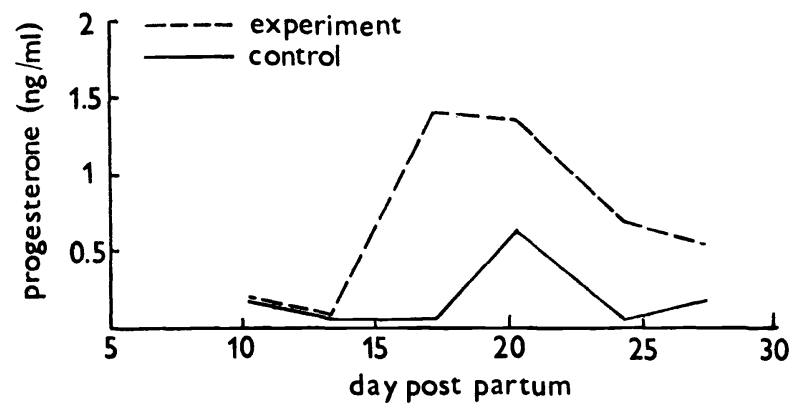

Fig. 2. Average level of milk progesterone in experimental and control cows.

Concentration of milk progesterone in experimental and control cows from day $9-10$ to day $30-31 \mathrm{pp}$ is shown in Fig. 2. Significantly higher levels $(\mathrm{p}<0.01)$ of milk progesterone were discovered in experimental cows during CIDR period $(1.4 \pm 0.75 \mathrm{ng} / \mathrm{ml})$ in comparison with previous values in the same cows $(0.1 \pm 0.26 \mathrm{ng} / \mathrm{ml})$ and with values in control cows during the same postpartum period $(0.2 \pm 0.51 \mathrm{ng} / \mathrm{ml})$. Term of the first postpartal ovulation, length of the lst sexual cycle and number of follicular waves during the 1st sexual cycle in experimental and control cows are included in Table 1.

Table 1

Term of the 1st postpartum ovulation (day pp), length of the 1st sexual cycle (days), and number of follicular waves during the 1 st sexual cycle in experimental and control cows

\begin{tabular}{|l|r|r|}
\hline & Experiment & Control \\
\hline 1st ovulation & $30.0 \pm 3.37$ & $19.5 \pm 7.85$ \\
1st sexual cycle & $24.0 \pm 2.45$ & $18.0 \pm 5.35$ \\
Follicular waves & $2.5 \pm 0.58$ & $2.0 \pm 0.82$ \\
\hline
\end{tabular}

Mean \pm s. d. 


\section{Discussion}

Insertion of intravaginal progesterone device day $14-15$ post partum decrease the possibility of occurrence of CL before and during CIDR period because generally the most of cows ovulate after this time and exogenous progesterone inhibits maturation and ovulation of the dominant follicles. None of our experimental cows had CL during this period. Inhibitory effect of CL to follicular population during CIDR period is described by Lucy et al. (1990). In accordance with this author we discovered a growth of large dominant follicle during progesterone intravaginal device period in cows not bearing CL and maintenance of the same number and size of medium follicles. But the growth of large dominant follicles was slower during progesterone treatment than in normal sexual cycle. The constant number and size of subordinant follicles is evidence of follicle dominance (Ireland and Roche, 1987).

- Interval to estrus is probably predictable from development of follicles at the time of CIDR removal. Large dominant follicles ovulated early (day 3 and 4 after CIDR removal) and medium dominant follicle became atretic followed by development of dominant large follicle on the contralateral ovary which ovulated later (day 9 after CIDR removal). The interval to estrus can already be predicted from the development of follicles at the time of CIDR insertion because the condition of ovaries did not change significantly during CIDR period.

In accordance with Lamond et al. (1971) reduced fertility after progestagen treatment may contribute to altered follicular growth and an increase in the number of atretic follicles. Our experiment demonstrates that large dominant follicles persisting during progesterone treatment for 10 days are capable of ovulation followed by the formation of normal CL with characteristic levels of milk progesterone. Sexual cycles with 2 or 3 follicular waves followed CIDR removal. Two or three waves of follicular development are characteristic for normal sexual cycle in heifers and cows (Rajakoski 1960; Pierson and Ginther 1987; Sirois and Fortune 1988). Average length of the first postpartum sexual cycle in experimental cows was significantly longer than in controls. These results support the conclusions of Sheffel et al. (1982) and Troxel and Kesler (1984) that progestagen pretreatment increases the proportion of cows which formed CL of a normal lifespan. Garcia-Winder et al. (1987) state that progesterone pretreatment supports development of a large dominant follicle with higher concentration of estradiol than follicles from non-treated cows. L kewise, Mee et al. (1991) describe higher secretion of estradiol by preovulatory follicles and lower concentrations of PGF 2 alpha-metabolite associated with prolonged postovulatory luteal function in progestagen treated cows. Apparently there is a limitation of progestagen treatment for the following fertility. Thimonier et al. (1975) describe lower conception rate after progestagen treatment for more than 10 days. Van Cleeff et al. (1989) report normal fertility after synchronization by 9 -day CIDR and PGF.

We conclude that progesterone intravaginal device treatment for 10 days is a possible method for the induction of ovulation followed by a normal sexual cycle in postpartal cows. 
Ovariální struktury sledované ultrazvukem v průběhu ošetření intravaginálním progesteronovým tělískem a v následujícím pohlavním cyklu u krav

Do pokusu byly zařazeny pluriparni krávy mléčného plemene (Norský skot). Intravaginální progesteronová tělíska (CIDR) byla vložena 4 experimentálním kravám od 14.-15. do 24. - 25. dne po porodu. Čtyři krávy v obdobné poporodní periodě tvořily kontrolní skupinu. U krav bylo prováděno transrektální ultrazvukové vyšetření ve 3-4dennich intervalech od 9.-10. dne po porodu do 2 . ovulace. Třikrát týdně byly odebírány vzorky mléka pro stanovení progesteronu RIA metodou. Folikulární populace byla rozdělena do 3 skupin - folikuly malé $(4-6 \mathrm{~mm})$, střední $(7-10 \mathrm{~mm})$ a velkém $(>10 \mathrm{~mm})$. Před a v průběhu ošetření CIDR tělískem nebylo u žádné $\mathrm{z}$ experimentálních krav zjištěno $\mathrm{CL}$. Dominantní velké folikuly pomalu rostly během CIDR periody a ovulovaly 3. a 4 . den po vybavení intravaginálního tělíska. $U$ jedné experimentální krávy se objevil dominantni středně veliký folikul 1 . den po vloženi tělíska, který podlehl atrézii. Druhý dominantní velký folikul, který byl zjištěn 1 . den po vybavení tělíska, za dalších 8 dní ovuloval. Během CIDR ošetření se stav středně velkých folikulů neměnil však počet malých folikulů se zvýšil. Jedna folikulární vlna byla zjištěna u kontrolních krav ovulujících před 20 . dnem po porodu, dvě folikulární vlny u krav ovulujících později. Termín 1. poporodní ovulace (den po porodu $30,0 \pm$ $\pm 3,37$ a $19,5 \pm 7,85)$, délka 1 . pohlavního cyklu $(24,0 \pm 2,45$ a $18,0 \pm 5,35$ dni) a počet folikulárních vln během 1 . pohlavního cyklu $(2,5 \pm 0,58$ a $2,0 \pm$ $\pm 0,82)$ u experimentálnich a kontrolních krav byly rozdilné. Hodnoty progesteronu v mléce během CIDR periody $(0,7-1,4 \mathrm{ng} / \mathrm{ml})$ byly průkazně $(\mathrm{p}<0,01)$ vyšší ve srovnání s hodnotami před vloženim intravaginálního tělíska a s hodnotami u kontrolních anovulačních krav $\mathrm{v}$ obdobném poporodním období.

Ošetřeni krav CIDR tělískem po dobu 10 dní považujeme za možnou metodu indukce 1. poporodní ovulace, kterou následuje normální pohlavní cyklus.

\section{Овариальные структуры, исследүемые үльтразвүком в ходе применения интравагинальных прогестероновых телец и в поспедүющий половой цикл коров}

В эксперимент включили многорожавшие коровы молочной породы (Норвежская порода). Интравагинальные прогестероновые тельца (CIDR) вставляли 4 экспериментальным коровам с 14-15 по 24-25 суток после отела. Четыре коровы аналогичного послеродового периода составляли контрольную группу. У коров проводили трансректальное ультразвуковое исследования в 3-4 суточные интервалы с $9-10$ суток после отела до 2 овуляции. Три раза в неделю отбирали пробы молока для определения прогестерона методом RIA. Фолликулярную популяцию разделили на 3 группы - малые фолликулы (4-6 миллиметров), средние (7- 10 мм) и большие $(>10 \mathrm{mм})$. Перед и в ходе применения прогестеронового тельца ни в одном случае не было у экспериментальных коров установлено CL. Доминирующие крупные фолликулы медленно росли в течение CIDR периода и их овуляция проходила 3-4 сутки после удаления интравагинального тельца. У одной экспериментальной коровы появился доминирующей 
средней величины фолликул через 1 сүтки после ввода тельца, который подвергся атрезии. Второй доминирующий крупный фолликул, выявленный 1 сүтки после удаления тельца, через следүющие 8 сүток овулировал. В ходе применения прогестеронового тельца состояние фолликулов средней величины не менялось, однако численность малых фолликулов увеличилась. Одна фолликүлярная волна была үстановлена у контрольных коров, овулирующих до 20 суток после отела, две волны - у коров, овулирүющих до 20 сүток после отела, две волны - у коров, овулирующих позднее. Сроки 1 послеродовой овуляции (сутки после отела $30,0 \pm 3,37$ и 19,5 $\pm 7,85$ ), продолжительность 1 полового цикла $(24,0 \pm 2,45$ и 18,0 $\pm 5,35$ сүток) и численность фолликулярных волн в течение 1 полового цикла $(2,5 \pm 0,58$ и $2,0 \pm$ $\pm 0,82)$ у экспериментальных и контрольных коров расходились. Величины прогестерона в молоке в течение периода $\operatorname{CIDR}(0,7-1,4 \mathrm{Hr} /$ /мл) были явно $(\mathrm{p}<0,01)$ выше по сравнению с величинами контрольных ановуляционных коров в аналогичный послеродовой период.

Применение прогестеронового тельца у коров в течение 10 суток следует считать возможным методом индүкции 1 послеродовой овуляции, после который следует нормальный половой цикл.

\section{References}

FULTON, R.-BALL, L.-WILTBANK, J. N.: Synchronization of estrus following 7 or 9 treatment with chlormadinone acetate (CAP). Theriogenology, 10, 1978: 73-80

GARCIA-WINDER, M. - LEWIS, P. E.-TOWNSEND, E. C.-INSKEEP, E. K.: Effects of norgestomet on follicular development in postpartum beef cows. J. Anim. Sci., 64, 1987: 1 099-1109

GAUTHIER, D. - COULAND, G. - VALLEE, F.: Induction d'une ovulation post-partum chez la vache créole á l'aide d'une séparation temporaire du veau et de l'utilisation préalable d'un implant de Norgestomet. Reprod. Nutr. Dévelop. 25, 1985: 1 029-1 035

IRELAND, J. J. - ROCHE, J. F.: Hypothesis regarding development of dominant follicles during a bovine estrous cycle. In: Roche JF, O'Callanghan D, (eds). Follicular Growth and Ovulation Rate in Farm Animals. Martinus Nijhoff, Publishers. The Hague, 1987: 1-18

LAMOND, D. R. - DICKEY, J. F. - HENRICKS, D. M. - HILL, J. R. Jr-LELAND, T. M.: Effect of progestin on the bovine ovary. J. Anim. Sci., 33, 1971: 77-82

LUCY, M. C. - THATCHER, W. W. - Mac MILLAN, K. L.: Ultrasonic identification of follicular populations and return to estrus in early postpartum dairy cows given intravaginal progesterone for 15 days. Theriogenology, 34, 1990: $325-340$

MEE, M. O. - STEVENSON, J. S. - MINTON, J. E.: First postpartum luteal function in dairy cows after ovulation induced by progestogen and gonadotropin-releasing hormone. J. Dairy Sci., 74, 1991: $1573-1581$

PIERSON, R. A. - GINTHER, O. J.: Follicular populations during the estrous cycle in heifers. I. The influence of day. Anim. Reprod. Sci., 14, 1987: 165-176

RAJAKOSKI, E.: The ovarian follicular system in mature heifers with special reference to seasonal, cyclical and left-right variations. Acta Endocrinol. (Suppl.)., 52, 1960: 7-68

RUTTER, L. M. - CARRUTHERS, T. D.-MANNS, J. G.: The postpartum induced corpus luteum: Functional differences from that of cycling cows and the effects of progesterone pretreatment. Biol. Reprod., 33, 1985: 560-568

SHEFFEL, C. E. - PRATT, B. R. - FERRELL, W. L. - INSKEEP, E. K.: Induced corpora lutea in the postpartum beef cow. II. Effects of treatment with progestogens and gonadotropins. J. Anim. Sci., 54, 1982: 830-836

SIROIS, J.-FORTUNE, J. E.: Ovarian follicular dynamics during the estrous cycle in heifers monitored by real-time ultrasonography. Biol. Reprod., 39, 1988: 308-317

SMITH, M. F.: Recent advances in corpus luteum physiology. J. Dairy Sci., 69, 1986: 911-926

SMITH, V. G. - CHENAULT, J. R. - McALLISTER, J. F. - LAUDERDALE, J. W.: Response of postpartum beef cows to exogenous progestogens and gonadotropin releasing hormone. J. Anim. Sci., 64, 1987: 540-551 
THIMONIER, J. - CHUPIN, D. - PELOT, J.: The control of reproduction in the nursing cow with a progestagen short-term treatment. Ann. Biol. Anim. Biochim. Biophys., 15, 1975: $263-272$

TROXEL, T.R. - KESLER, D. J.: The effect of progestin and GnBH treatment on ovarian function and reproductive hormone secretions of anestrous postpartum suckled beef cows. Theriogenology, 21, 1984: 699-711

Van CLEEFF, J. - MACMILLAN, K. L.-THATCHER, W. W. - LUCY, M. C.: Estrus synchronization and fertility in heifers treated with CIDR before and after insemination. J. Anim. Sci. (Suppl. 1), 67, 1989: 383 abstr.

WHITE, L. M. - KEISLER, D. H.-DAILEY, R. A. - INSKEEP, E. K.: Characterization of preovulatory follicles destined to form "subfunctional" corpora lutea. Biol. Reprod. (Suppl. 1), 32, 1985: $43-56$

ZIMBELMAN, R. G.: Determination of minimum effective dose of $6 a$ - methyl - 17a - acetyoxyprogesterone for control of the estrual cycle of cattle. J. Anim. Sci., 22, 1963: $1051-1058$ 